Communication

\title{
Taking on the Big Issues and Climbing the Mountains Ahead: Challenges and Opportunities in Asia
}

\section{John Richardson}

Lee Kuan Yew School of Public Policy, National University of Singapore, 469C Bukit Timah Road, Singapore 259772; E-Mail: jrich@american.edu; Tel.: +65-6691-3037; Fax: +65-6799-5397

$\dagger$ This paper builds on an opening plenary address to the inaugural Asia-Pacific System Dynamics Conference held on 22-24 February 2014 in Tokyo, Japan.

Received: 3 June 2014; in revised form: 2 August 2014 / Accepted: 6 August 2014 /

Published: 11 August 2014

\begin{abstract}
At the 2007 International System Dynamics Society Conference, Professor Jay Forrester posed a challenge: "We need books addressed to the public that are understandable, relevant, important and dramatic". We need to overcome the "constraints of academe" that inhibit path-breaking work. We need to address "the big issues". We need to march "upward from the present aimless plateau and start climbing the mountains ahead". This was a message that was intended to inspire and empower, not to criticize. Responding to Professor Forrester's challenge, this paper first describes the work of three inspiring role models, Dennis Meadows, Junko Edahiro and John Sterman. They have demonstrated how books can have an impact on people's lives, how "big issues" can be addressed, how the constraints of academe can be overcome and how mountains can be scaled. Second, it offers grounds for optimism about the future of system dynamics modeling in Asia, gained from my sojourn at the National University of Singapore. Third, it describes three "mountains ahead" to be scaled and highlights the work of individuals who have already begun the journey.
\end{abstract}

Keywords: system dynamics; The Limits to Growth; C-Roads Project; sustainable development; human happiness 


\section{Introduction: A Message from Professor Jay Forrester: The "Zen Master" of System Dynamics Modeling}

Had Professor Jay W. Forrester been with us on this special day, inaugurating the System Dynamics Society's new Asia-Pacific outreach, what message might he have brought us? It might have been similar to the "caning" of a Zen master; similar to the message he delivered to the International System Dynamics Society Conference in 2007. He told assembled participants that after a period of growth, our field "has stagnated on an aimless plateau". "We need to address the big issues". "We need books addressed to the public that, like Urban Dynamics, World Dynamics and Limits to Growth are understandable, relevant, important and dramatic. We must focus debate in newspapers, blogs, League of Women Voters' meetings and parent-teacher associations". The constraints of academia are stifling the work of junior faculty while "senior faculties have settled comfortably into writing for professional journals rather than on matters of public concern". Many are trying to "dumb down" system dynamics into systems thinking and causal loop diagrams. At the end of this verbal caning, he left delegates with a challenge: "to plan for marching upward from the present aimless plateau and start climbing the mountains ahead" [1].

The importance of his message, of course, was not the critique of what was wrong, but an envisioning of what could be. Perhaps he was suggesting, as Kim Warren did in his July 2013 International System Dynamics Society "Presidential Address", that we spend more time seeking out experiences and opportunities with the potential to empower and inspire [2].

In a similar vein, but without the caning, this paper offers three points. The first is about personal role models who have inspired me. You may have heard of them, but may not know that much about them. They have shown how books can be made powerful. They have empowered the general public to engage with big issues in their daily lives. They have demonstrated that the constraints of academe can be overcome. Second, it offers grounds for optimism about the future of system dynamics modeling in Asia, gained from my sojourn at the National University of Singapore. Third, it describes three "mountains ahead" to be scaled and highlights the work of individuals who have already begun the journey.

\section{Three Personal Role Models Who Have Inspired Me}

\subsection{Dennis Meadows}

Why do I believe that my friend of more than 30 years, Dennis Meadows, can serve as an inspiring role model?

When Professor Forrester expressed concern about the need for a genre of books having an impact that changed people's lives, he mentioned The Limits to Growth [3], along with Urban Dynamics [4] and World Dynamics [5]. Perhaps he might have given more credit to the long-lasting impact of The Limits to Growth and its successor volumes, Beyond the Limits [6] and Limits to Growth: the 30 Year Update [7].

As is widely known, this project was a partnership between Dennis and Dana Meadows until Dana's tragic and untimely death on 20 February 2001. Dennis and Dana had many achievements as individuals. However, in partnership, they provided an object lesson in what is required for a book-or in this case a series of books - to become powerful. 
After Dana's death, Dennis committed himself further to keeping the message of The Limits to Growth alive-by producing a third iteration [7]. He has been an eloquent, itinerant advocate for the issues raised in the three volumes, giving at least hundreds and perhaps thousands of presentations throughout the world.

A noteworthy example of Dennis and Dana's continuing engagement was their founding of the Balaton Group, a network of scholar practitioners concerned with sustainability, in 1982. Recently the Balaton Group celebrated its 30th anniversary. It is among the most notable examples of the institutions and public outreach activities that Dennis and Dana created and sustained, to help ensure that the message of The Limits to Growth and its successor volumes remained viable and powerful.

\subsection{Junko Edahiro}

I first had the privilege of meeting my second inspiring role model, Junko Edahiro, when she was invited to the 2002 meeting of The Balaton Group [8] as one of the first Donella Meadows Fellows. If you want to know how to focus on the big issues and raise them in public consciousness, consider Junko's remarkable career. By the time we met, she had already established herself as a respected environmental journalist, using skills developed as a simultaneous Japanese-English translator to make books and articles on environmental issues and sustainable development available to Japanese audiences. Her book in Japanese, with the English title, If You Get Up At Two You Can Do Whatever You Want To Do captures the essence of Junko's work-ethic and helps explain why she has been one of my most inspiring personal role models ever since our paths first crossed (Unfortunately the book is not available in English).

Junko's biography describes her as “Social Entrepreneur, Environmental Journalist and Translator" [9]. It lists her as affiliated with nine organizations, many in the position of founder and President. Admirers have named her as Japan's "First Lady of the Environment" [10].

In collaboration with her colleague, Rich Oda, she conducts systems thinking workshops and has brought leaders in systems thinking and system dynamics modeling, such as Dennis Meadows and Peter Senge, to Japan. The newsletter of the organization she founded in 2002, Japan for Sustainability, publishes monthly in both Japanese and English [11]. She has translated or overseen the translation of four system dynamics modeling and systems thinking classics, including John Sterman's Business Dynamics [12]. She has also written books, articles and instruction manuals on systems thinking in Japanese.

Most recently, she has founded the Institute for Studies in Happiness, Economy and Society about which I shall have more to say shortly. Junko may not devote much of her time to system dynamics modeling, but there are few individuals who have been more effective, in any country, at raising big issues, viewed from a system dynamics vantage point. With skill, creativity and passion, she has brought them to the attention of both national leaders and ordinary citizens.

\subsection{John Sterman}

Finally, if you are looking for a role model to convince you that academic cultures need not be constraints and that system dynamics need not be "dumbed down", consider the career of my third role model, John Sterman. 
John Sterman exemplifies a commitment to tackling the big issues, engaging in public discourse, and, perhaps most notably, achieving long-term viability for the field of System Dynamics at MIT. $\mathrm{He}$ is an award-winning teacher and scholar. He is a demanding and empowering mentor of doctoral students.

John's classic, Business Dynamics: Systems Thinking and Modeling for a Complex World [12], convincingly refutes those who question the mathematical rigour and scientific foundations of system dynamics modeling. Economists and management science academics cannot dismiss his publications. He can speak their language and has published in their top ranked journals. He has made major contributions to the field of organizational learning. He has developed innovative games and made them widely accessible. And just when one might have thought that John had accomplished all that there was to be accomplished, he began climbing an entirely new mountain with the C-Roads Climate Interactive Project [13], to which I will return.

\subsection{Common Threads}

Having briefly chronicled the contributions of these three role-models, one might legitimately pose the question, as did one of this paper's referees, "are there qualities that they have in common, apart from serving as role models who have personally inspired me and many others?" Courageous engaging with "big issues" and raising the profile of those issues in the perceptions of general publics are the qualities that are most noteworthy. However the differences are as noteworthy as the similarities. This is good news, in my opinion. System dynamics modelers seeking role models need not feel bound to a single template as they seek out life paths that will provide personal fulfillment, create new knowledge and contribute to human well being. My three role-models do have much in common but have traversed very different paths to achieve their current level of eminence. Let me elaborate further, very briefly.

With an assist from the Club of Rome, Dennis Meadows (and Dana Meadows too) embarked on the turbulent, demanding path of the public intellectual, addressing highly controversial issues during a very early chapter of his professional life. Though his contributions in other areas have been noteworthy, refining and keeping The Limits to Growth's message alive has remained a central focus.

John Sterman chose a more conventional path emphasizing teaching, research and institution building. He attended to a challenge that had not been given priority by his mentor, Jay Forrester, building bridges to other disciplines and securing the place of system dynamics at MIT. His tackling of a "big issue" and emergence as a public intellectual came later. However, as will be told below, he has now embarked on that path with passion, discipline and skilled leadership.

Like John Sterman, Junko Edahiro defined herself as a public intellectual, building on her translation skills, commitment to systems thinking, and an incredibly disciplined work ethic somewhat later in life. What is noteworthy about her career, as will be told below is how she has expanded the scope of her concerns from sustainability to encompass the larger issue of envisioning a human society in which motivations of self-interest are supplanted by more altruistic motivations emphasizing human happiness. 


\section{Grounds for Optimism about the Future of System Dynamics in Asia, Gained from my Sojourn in Singapore}

Let me next turn to the subject of academic institutions and, in particular, to the Lee Kuan Yew School of Public Policy at the National University of Singapore, where I now hold an appointment as Visiting Professor.

\subsection{The Lee Kuan Yew School of Public Policy}

It would be disingenuous to claim that the criticisms directed towards academic institutions by Professor Forrester - assistant professors who are afraid of making waves, senior professors that have settled into comfortable lives, priority given to publishing in "high impact" journals with little policy relevance, are imaginings.

Donella Meadows provides one example of a highly regarded systems thinker and modeler who was acutely conscious of the issues to which Professor Forrester's critique pointed. These contributed to her decision to give up a half-time tenured professorship at Dartmouth College, though they were not the only considerations.

However many senior scholar-practitioners in our field, including Dennis Meadows and John Sterman have functioned quite successfully in academic environments. The State of University of New York at Albany has provided a home for the System Dynamics Society and for two of the most eminent scholars in the system dynamics modeling community, George Richardson and David Anderson. I should also note that Industrial Dynamics [14], Urban Dynamics [4] and The Limits to Growth [3] were all written by individuals who were formally affiliated with MIT.

The Lee Kuan Yew School and the National University of Singapore, while not immunized from the problems to which Professor Forrester directs our attention, do appear to offer some distinctive features from which useful lessons can, perhaps, be drawn.

In my "Lifetime Achievement Award" address, given at the June 2013 System Dynamics Society International Conference [15], I recounted the improbable tale that lead to my present affiliation. Our system dynamics modeling course was catalyzed by two faculty members, whose modeling skills were complemented by extensive experience in public discourse and public policy. One was taking leave from a career at the Asian Development Bank. The other was a former journalist. Though still an elective, the course is being offered for a fourth year and by the end this Spring semester, will have reached nearly 100 students, including some enrolled in the Faculty of Engineering, the Department of Geography, the University Honours Program for undergraduates and the Duke-National University of Singapore Medical School.

Most students at the Lee Kuan Yew School enroll with the intention of pursuing public policy careers. Many have already begun such careers and will return to them. Students who complete our course are required to complete original system dynamics modeling projects. They compare favorably with papers that I have refereed and recommended for presentation at System Dynamics Society International Conferences.

However, quality work is not enough. Solid presentation skills are required. Our students are required to present their results using the Pecha Kucha format first pioneered by a community of architects in Japan [16]. 
In 2013 - this too I mentioned in my July 2013 address [15] — our course culminated in a public event where students presented 18 original modeling projects using a modified Pecha Kucha format. 29 guests from the wider Singapore community, including representatives from four government ministries, three research institutes, three other Singapore universities and two for-profit consulting groups attended. Most remained for the entire three hours of presentations.

\section{2. "Professor in the Practice of Public Policy": Dean Kishore Mahbubani}

What explains the supportive environment for public policy research on the part of both faculty and students at the Lee Kuan Yew School of Public Policy and at other institutions characterized by a similarly supportive climate? I believe the leadership on the part of a supportive, effective dean who is committed to public policy research is essential. It is not enough for such a dean to profess support for research that focuses on the big issues and makes results of that research widely available. More important, he or she must exemplify that commitment in his or her own research, providing a visible and influential role model for both students and faculty.

While I conducted no survey to validate this observation, I doubt there are many deans that exemplify such a commitment with greater visibility and effectiveness than the Lee Kuan Yew School's Dean, Kishore Mahbubani. A check of Kishore's website reveals categories for "Books", "Articles", "Interviews", and "Media." In addition to his latest book, The Great Convergence-Asia, the West and the Logic of One World [17] along with scores of articles, interviews and media appearances, he has already published widely in 2014, with all of his contributions addressing what might be legitimately termed "big issues". In April 2014, Jonathan Derbyshire, Editor of the British Public Affairs Journal, Prospect, announced that Dean Mahbubani had been named to its list of "Top 50 World Thinkers" [18]. In this regard, the title of Dean Mahbubani's academic appointment, Professor in the Practice of Public Policy, is revealing. It conveys an important message of which Professor Forrester would approve, I believe.

\subsection{System Dynamics Modeling at the National University of Singapore}

While system dynamics modeling now appears to have found a secure position among elective course offerings at the Lee Kuan Yew School of Public Policy, interest in the field has also become a matter of interest to the National University of Singapore's President and Central Administration.

In 2009, NUS President Tan Chorh Chuan formed an ad hoc "Core Group" to explore the possibility that system dynamics might serve as a core methodology for the University's newly created Global Asia Institute. The faculty member who had catalyzed the teaching of System Dynamics modeling at the Lee Kuan Yew School, Visiting Professor K.E. Seetharam, was named to head the Institute. Chairing the task force was one of Singapore's most respected retired civil servants, Professor Lui Pao Chuen, who was also a strong system dynamics advocate.

In a 29 October 2010 "White Paper," submitted to President Tan, the Core Group recommended system dynamics as a core research methodology for the Global Asia Institute. "As a conceptual framework and methodology", its report concluded, "system dynamics integrates the best thinking of multiple disciplines and provides a mature yet evolving methodology for conceptualizing new theory". 
The goal of what we called the Global Asia Institute's System Dynamics Initiative was to evolve a group, combining research and teaching that was patterned after MIT's System Dynamics Group. However a university-wide research institute without teaching responsibilities proved not to be the most effective platform for a university wide program. Those of us involved in the System Dynamics Initiative were reminded that if the "mountain" of institutionalizing system dynamics in a new university setting is to be scaled, strong teaching, as well as high impact research must be part of the picture. Now, new initiatives have been envisioned that include a strong teaching component.

\subsection{Why Singapore Seems a More Receptive Environment for Public Policy Applications of System Dynamics Modeling than the US and a Point of Leverage for China's Public Policy?}

This paper is based on an address that was given to help inaugurate System Dynamics SocietyAsia-Pacific Region focused initiatives. There can be no doubt of the region's intrinsic importance, but how receptive are Asia-Pacific public policy processes likely to be to such initiatives? Generalizing about such a diverse region as a whole would be unrealistic. However it seems appropriate to elaborate further on why I chose Singapore as the focus of my own work, why Singapore's public policy environment has proved to be receptive, and why this receptivity is relevant to the nation whose public policies, in my view, will be most influential in shaping the region's future development, China.

Why Singapore? An examination of public policies contributing to Singapore's post independence success story makes it clear that systems thinking played an important role. The systems-thinking-oriented views of Singapore's two most important post-independence leaders, Lee Kuan Yew [19] and Goh Keng Swee [20] were particularly influential. In two papers [21,22], Elizabeth Ong and I have noted close correspondences between Singapore's development trajectory and policy guidelines emphasized in Urban Dynamics. This does not, however, fully explain the continued receptivity to systems thinking and modeling that I have personally experienced and that has been experienced by others. Fully documenting this would require a separate paper. However examples with which I am personally familiar include training programs conducted by the Civil Service College, the Ministry of Defense, and the Population and Talent Division, Office of the Prime Minister. Programs at Singapore's flagship National University of Singapore have already been mentioned. Soon, these will also include an initiative being developed by the new Director of the NUS-Based Temasek Defense Systems Institute, in which I will be personally involved.

In my 2013 plenary address to the 31st International System Dynamics Society Conference [15], I sought to explain this phenomenon, which differs so greatly from my personal experience of the US Public Policy environment, beginning with President Ronald Reagan's administration. I pointed to three factors that appeared to be particularly consequential. "First is the degree to which Singapore's political-social economy has been shaped by the systems thinking of its founding political leaders... This has been carried forward by their successors. Systems thinking has been institutionalized through planning and regulatory schemes... that are uniquely Singaporean".

"Second is the typical profile of Singapore's top leaders, especially those who occupy all-important Ministerial and Permanent Secretary positions. Most have educations that combine degrees in science, technology, and engineering, and with additional graduate work in public administration and management. All of the men have military service in their background, with a number having risen to 
very senior positions in the army and navy". When system dynamics models are effectively presented, even by students just completing their first semester of work, these leaders quickly grasp their usefulness for aiding public policy systems design and decision making.

"Third is the strong emphasis on science and technology in Singapore's secondary schools". This makes Singapore an unusually receptive environment for achieving the late Barry Richmond's goal, shared by 2011 Lifetime Achievement Award recipient Diana Fisher and many others, of creating a society populated by "systems citizens" [23].

I have described considerations that make Singapore an intrinsically promising public policy venue for system dynamics modeling, however viewed from an Asian perspective, those considerations are not the most compelling. More compelling is Singapore's past and continuing role in shaping the practice and direction of public policy in China. Ever since Deng Xiaoping's iconic visit to Singapore and conversations with Lee Kuan Yew in 1978 [19,24], Singapore has served as a beacon light and model for Chinese leaders regarding matters of governance and economic development. It is not the only model to be sure, but it remains an important one. Though others may differ, I believe that at this juncture, the applications of systems thinking and system dynamics modeling now being catalyzed in Singapore may have an even greater impact on China and perhaps other Asian countries as well, than were one to attempt introduction of those applications locally. As it has been in the past, Singapore can be a high leverage launching pad for such applications.

\section{Conclusions: "Climbing the Mountains Ahead"}

What other "mountains" should attract the vision, energy and dedication of present and future system dynamics scholar-practitioner-promoter-activists? I should like to share three, of surpassing importance, that top my list.

\subsection{Economic Dynamics}

First is the one to which I called attention in my July 2013 address [15]. I named it the fourth pillar in Professor Forrester's Legacy, a legacy that now comprises the insights we have gained from Industrial Dynamics [14], Urban Dynamics [4] and World Dynamics [5]. I am referring to his long-promised transformational book on economic dynamics, a project to which many members of the system dynamics modeling community have contributed.

There must also be a popularized version of that work, exhibiting the qualities of The Limits to Growth and its successor volumes that Professor Forrester has described so eloquently. Professor Khalid Saeed has now embarked on work that points in this direction [25]. He needs our encouragement and support, as well as the companionship of some hardy mountain climbers to accompany his trek. There may be no more important contribution that could be made, not only to the practice of system dynamics modeling, but also to the well-being of the human species, at this time in history.

\subsection{The C-Roads Climate Interactive Project}

A journey up a second mountain, transforming public and political consciousness, regarding the relationship between industrial development and climate change, is well underway. 
In a user-friendly website and many presentations, both to policy makers and general publics, John Sterman and colleagues have described the basic elements of this path-breaking project. It is designed to be fast, generating climate change scenarios in response to policy interventions in less than a second. It is designed to be accessible. Its flexible, intuitive interface can be used easily on a laptop by individuals with no modeling experience. The model assumptions are transparent. The assumptions are "open box" accessible and available for review. A causal tracing feature permits auditing of behaviour. Finally, it is grounded in and consistent with accepted climate science. It has been reviewed by a distinguished panel of scientists and tested against other well-regarded models and data. Its structure and interface enable rapid and flexible sensitivity analysis [26].

However to capture public attention, there needs to be more than good science and good software interfaces to make that science accessible. Passionate, visionary project leadership is also needed. John Sterman is providing that essential ingredient. When, as a member of a large audience, I first heard John speak about the C-Roads Project from a distant platform, I was reminded of the Prophet Jeremiah, exhorting the people of Israel to refrain from their wayward ways or face the consequences if they did not. John brings a passion to this work that I had not seen in his earlier endeavours, path breaking though they have been. Perhaps passion is another ingredient that is needed if one is to climb mountains.

\subsection{Modeling a Stable, Sustainable, Economically Viable Human Society that Maximizes Human Well Being}

My third "mountain" is a role for system dynamics modeling in creating economies and societies that seek to maximize human well being. What I envision is a model that incorporates elements of the models described in Urban Dynamics and World Dynamics and that falls somewhere between the two of them in size. It also draws from the examples of two other system dynamics models, to be cited below, that sought to capture relevant ideas of fundamental importance for which no "hard data" was available.

This envisioning was motivated by another Junko Edahiro initiative, The Institute for Studies in Happiness, Economy and Society (ISHES), which held its inaugural event on March 4, 2011. Here is the Institute's mission statement - the highlighting is my addition:

ISHES plans to develop activities such as conducting research and studies, disseminating study results, shaping public opinion, encouraging dialogue, building networks to respond to world trends, and squarely addressing important questions, including How should we deal with the limits of the Earth to build a truly happy society without making society and the economy unstable? and What indicators should we use to measure society's true progress and happiness? [27].

\subsection{What Makes These Three Projects, and the Mountains They Seek to Climb, Important and Distinctive?}

Those of us who first engaged in "global modeling" can remember the rage which greeted presentations of the idea that limiting growth in capital accumulation, population, food production, natural resource consumption and pollution might be necessary to ensure the survival of the human species on planet earth. In a highly accessible survey volume, Life Beyond Growth [28], "sustainable development" scholar-activist Alan Atkisson documents the deeply rooted attitudes, embedded in and 
reinforced by dominant social-political institutions, that evoked these emotional reactions. The "growth paradigm" and the inevitability that it would produce good outcomes for the human species was an accepted, indisputable fact of life. It remains so today, though as Atkisson's survey highlights, new paradigms are emerging. Among many examples, prestigious mainstream documents such as the Report by the Commission on the Measurement of Economic Performance and Social Progress [29], and the Royal Society's People and the Planet report [30], demonstrate this.

Each of three projects I have highlighted has the potential to further the process of paradigm change that Atkisson's survey catalogues. ISHES and C-Roads have already achieved success. What are the qualities that evoke my optimism?

First, each is being lead and catalyzed by highly regarded, action-oriented members of the system dynamics community.

Second, because of this, C-Roads and, the work of ISHES have demonstrated that creating compelling, accessible deliverables based on work of high scholarly quality will not be a problem. Life Beyond Growth is, in fact an ISHES deliverable. Output from the project to fundamentally reshape economic thought, based on Professor Forrester's seminal but as yet incomplete theories and models should be the most compelling and high profile of all. Professor Khalid Saeed's recent work demonstrates what is possible [25].

Third, each project recognizes that changing attitudes both within institutions and among the public whose attitudes both shape and are shaped by institutions must be the overarching goal. Both the C-Roads and the ISHES projects have made progress in developing technologies that will facilitate attitude change. The Landmark BBC Series, Century of the Self, showing how Freudian Psychologist and public relations guru, Edward Bernays, implemented programs that, in the post war era "transformed American consumers from frugal savers to hungry consumers" [28] illustrates what is possible. To cite another example, Singapore's government, too, has achieved landmark (albeit sometimes controversial) results with programs intended to build patriotism, mutual respect, a "clean and green Singapore", and communal harmony among its citizens.

Fourth, each project questions attitudes emphasizing that maximizing economic growth combined with unconstrained functioning of the profit motive represent the surest paths to universal human well-being and the survival of our species. However powerful compelling demonstrations that maximizing human happiness through attitudes that emphasize altruistic compassion will produce better results remain to be demonstrated. Since producing such demonstrations is my mountain, this observation leads me to a concluding postscript.

\subsection{Postcript}

No one could doubt that the question defining the ISHES mission is an important one. But "What does this have to do with challenges and opportunities for system dynamics in Asia?" one might ask.

Here are my answers.

First, when, as a young faculty member, in 1972, I was told that Professor Jay Forrester was building a computer model of the world, I thought it was a joke. Two years later, I had helped develop such a model [31] and ten years later, I had co-authored a book about seven of them [32]. 
In 1978, Jack Homer, one of the most creative members of the system dynamics modeling profession created and described a system dynamics model, in a paper titled "Civilization as Enterprise" [33] that encompassed major theories describing the rise and fall of human civilizations.

In 1981-1982, John Sterman built and described a system dynamics model in several papers, beginning with "The Growth of Knowledge: Testing a Theory of Scientific Revolutions with a Formal Model" [34-36] that represented the dynamic described by Thomas Kuhn in his classic, The Structure of Scientific Revolutions [37].

The task of building system dynamics models that seek to answer the question "how should we deal with the limits of the earth to build a truly happy society, without making that society and the economy unstable" may be a difficult one. However, these examples, chosen from among many more, demonstrate that such a task is not impossible.

It is simply another mountain that is worth climbing.

I look forward to welcoming the companions who will join with me on this journey.

\section{Acknowledgments}

As noted above, an earlier version of this paper was given as an opening plenary address to the inaugural Asia-Pacific Conference of the System Dynamics Society. The organizational efforts of the conference chair, Akira Uchino, and the program chair, Bob Cavana, are gratefully acknowledged. My colleagues at the Lee Kuan Yew School of Public Policy, Elizabeth Ong Ling Lee and Kwan Chang Yee, also offered ideas, support and patient listening, as did my partner in many system dynamics modeling endeavors, Global Asia Institute staff member, Rehan Ali. The offering of a module in system dynamics modeling and other initiatives described in my paper would not have been possible without the support of Dean Kishore Mahbubani, who despite many commitments as a leader and public intellectual, is also welcoming to visitors and open to proposals for innovative public policy research and teaching initiatives.

\section{Conflicts of Interest}

The author declares no conflict of interest.

\section{References}

1. Forrester, J.W. System dynamics-The next fifty years. Syst. Dynam. Rev. 2007, 23, 359-370.

2. Warren, K. Taking the Opportunity. 2013 Presidential Address. In Proceedings of the 31st International System Dynamics Society Conference, Cambridge, MA, USA, 21-25 July 2013.

3. Meadows, D.H.; Meadows, D.L.; Randers, J.; Behrens, W.W., III. The Limits to Growth; Universe Books: New York, NY, USA, 1972.

4. Forrester, J.W. Urban Dynamics; MIT Press: Cambridge, MA, USA, 1969.

5. Forrester, J.W. World Dynamics; Pegasus: Waltham, MA, USA, 1971.

6. Meadows, D.H.; Meadows, D.L.; Randers, J. Beyond the Limits: Confronting Global Collapse, Envisioning a Sustainable Future; Chelsea Green Publishing: White River Junction, VT, USA, 1992. 
7. Meadows, D.H.; Meadows, D.L.; Randers, J. Limits to Growth: The 30-Year Update; Chelsea Green Publishing: White River Junction, VT, USA, 2004.

8. The Balaton Group. Available online: http://www.balatongroup.org (accessed on 3 June 2014).

9. Junko Edahiro Biography: About Us-Institute for Studies in Happiness, Economy and Society. Available online: http://ishes.org/en/aboutus/biography.html (accessed on 11 February 2014).

10. The Japan Times, Life, Asia's First Lady of the Environment. Available online: http://www. japantimes.co.jp/life/2008/11/26/environment/asias-first-lady-of-the-environment/\#.U1zHEq2SxEN (accessed on 11 February 2014).

11. JFS. Japan for Sustainability (in English). Available online: http://www.japanfs.org (accessed on 3 June 2014).

12. Sterman, J. Business Dynamics: Systems Thinking and Modeling for a Complex World; Irwin McGraw Hill: Boston, MA, USA, 2000.

13. C-ROADS. Available online: http://www.climateinteractive.org/tools/c-roads/ (accessed on 3 June 2014).

14. Forrester, J.W. Industrial Dynamics; Pegasus: Waltham, MA, USA, 1961.

15. Richardson, J. The past is prologue: Reflections on forty-plus years of system dynamics modeling practice. Syst. Dynam. Rev. 2013, 28, 172-187.

16. PechaKucha 20X20: Frequently Asked Questions. Available online: http://www.pechakucha.org/ faq (accessed on 11 February 2014).

17. Mahbubani, K. The Great Convergence-Asia, the West and the Logic of One World; Public Affairs: New York, NY, USA, 2013.

18. Kishore Mahbubani in Top 50 List of World Thinkers. Available online: http://news.nus.edu.sg/ press-releases/7535-kishore-mahbubani-in-top-50-list-of-world-thinkers (accessed on 2 April 2014).

19. Yew, L.K. From Third World to First: The Singapore Story: 1965-2000; Marshall Cavendish Editions: Singapore, 2000.

20. Sun, T.S. Goh Keng Swee: A Portrait; Editions Didier Millet: Singapore, 2007.

21. Richardson, J.; Ong, E. The Relevance of Urban Dynamics to Singapore's Success Story: Lessons for Moving Beyond the Crisis. In Proceedings of the 28th International System Dynamics Society Conference, Seoul, Korea, 25-29 July 2010.

22. Richardson, J.; Ong, E. The improbable resilience of Singapore. Solutions 2012, 5, 63-71.

23. Fisher, D.M. Everybody thinking differently: K-12 is a leverage point. Syst. Dynam. Rev. 2011, 27, 394-411.

24. Vogel, E.F. Deng Xiaoping and the Transformation of China; The Belknap Press of Harvard University Press: Cambridge, MA, USA, 2011.

25. Saeed, K. Three Slices of Jay Forrester's General Theory of Economic Behaviour; Working Paper, SPSS dept. WPI R-1; Worcester Polytechnic Institute: Worcester, MA, USA, 2013.

26. Climate Interactive: Tools for a Thriving Future. Available online: http://www.climateinteractive. org/tools/c-roads (accessed on 11 February 2014).

27. Institute for Studies in Happiness, Economy and Society. Available online: http://ishes.org/en/ news/2011/inws_id000138.html (accessed on 11 February 2014). 
28. Atkisson, A. Life beyond Growth: Alternatives and Complements to GDP-Measured Growth as a Framing Concept for Social Progress; Institute for Studies in Happiness, Economy and Society: Tokyo, Japan, 2012.

29. Report by the Commission on the Measurement of Economic Performance and Social Progress. (Professor Joseph E. Stiglitz, Chair). Available online: http://www.stiglitz-sen-fitoussi.fr (accessed on 8 July 2014).

30. People and the Planet; The Royal Society Policy Centre Report 01/12; The Royal Society: London, UK, 2012.

31. Mesarovic, M.D.; Pestel, E. Mankind at the Turning Point; Dutton: New York, NY, USA, 1974.

32. Meadows, D.H.; Richardson, J.; Bruckmann, G. Groping in the Dark: The First Decade of Global Modeling; John Wiley \& Sons: Chichester, UK, 1983.

33. Homer, J.B. Civilization as Enterprise: The Life Cycle of Cultural Production; D-2951; System Dynamics Group, MIT: Cambridge, MA, USA, 1978.

34. Sterman, J. The Growth of Knowledge: Testing a Theory of Scientific Revolutions with a Formal Model; D-2909-3; System Dynamics Group, MIT: Cambridge, MA, USA, 1982.

35. Sterman, J. The Growth of Knowledge: Testing a theory of scientific revolutions with a formal model. Technol. Forecast. Soc. Change 1985, 28, 93-122.

36. Sterman, J.; Wittenberg, J. Path dependence, competition and succession in the dynamics of scientific revolution. Organ. Sci. 1999, 10, 322-341.

37. Kuhn, T.S. The Structure of Scientific Revolutions; The University of Chicago Press: Chicago, IL, USA, 1962.

(C) 2014 by the authors; licensee MDPI, Basel, Switzerland. This article is an open access article distributed under the terms and conditions of the Creative Commons Attribution license (http://creativecommons.org/licenses/by/3.0/). 